\title{
The Implications of Harmonization of European Contract Law on International Business Practice
}

\author{
Katarzyna Jagodzinska ${ }^{1}$ \\ ${ }^{1}$ Enterprise Institute, University of Neuchâtel, Neuchâtel, Switzerland \\ Correspondence: Katarzyna Jagodzinska, Enterprise Institute, University of Neuchâtel, Rue A.-L. Breguet 1, \\ office 306, CH - 2000 Neuchâtel, Switzerland. Tel: 41-32-718-1567. E-mail: katarzyna.jagodzinska@unine.ch
}

\author{
Received: February 5, 2014 Accepted: March 14, 2014 Online Published: April 15, 2014 \\ doi:10.5539/ilr.v3n1p16 URL: http://dx.doi.org/10.5539/ilr.v3n1p16
}

\begin{abstract}
This paper strives to enhance the reader's understanding of the concept of harmonization of European contract law from the point of view of modern business practice. The aim of the article is to critically assess the harmonization proposal in view of its' practical benefits. The article commences with a brief historic overview of the harmonization proposal aimed at highlighting the multiple controversies linked to the harmonization efforts. The historical, theoretical, legal and business aspects of the harmonization proposal are successively taken into account. The ultimate goal of this paper is to draw the reader's attention to those aspects of the harmonization proposal which could impact operational management, in particular at the level of international companies. The author identifies such potential benefits as: reduction of barriers to internationalization and stimulation of economic growth at the SME level, enhanced understanding of standards and procedures of business conduct, reinforced communication between international parties, lower transaction and operational costs, less need for external expertise and legal advice, and prevention of potential conflicts. This paper shows that a results-driven, clear focus on the practical advantages of the harmonization of European contract law can ultimately transform what is now merely an academic exercise into a practical business tool.
\end{abstract}

Keywords: cross-border transactions, Draft Common Frame of Reference, European contract law, harmonization, international business, internationalization, operational management

\section{Introduction}

On numerous occasions in the course of my professional activities related to European contract law, international business operations, as well as several years of lecturing practice in translation of European Union legislation, I have had the opportunity to observe that law no longer holds the privilege of an isolated domain, but rather is the end product of a combination of law, business and language. The effort to bring together national legal systems of multilingual and multicultural Member States in view of introducing a novel concept, such as the harmonization of European contract law, is a perfect example of evolutionary changes in social sciences triggered by volatile market conditions, growing internationalization, increased number and complexity of business transactions to name just a few. In my opinion, the attempt at harmonization calls for innovative solutions and a broader, perhaps less traditionally bound outlook. The topic of this paper reflects this need and attempts to satisfy it. Consequently, its' scope of application lies somewhere on the borderline where the three domains: law, business and language meet.

From a practical point of view, all European businesses encounter the same reality and are currently facing similar problems. They are functioning in a more international, complex and competitive environment, whether in a domestic or broader market. Even if a company is operating only in the national market it will be influenced by international competition and new legal regulations. Conducting business in this highly dynamic environment is inevitably more complicated and requires businesses to adapt, apply novel rules, establish new legal practice and deal with a wide range of economic decisions. For many companies, harmonization of European contract law is a way of overcoming the complexities associated with international business transactions. Analyzing the impact of harmonization on companies provides fertile ground for understanding the concept itself and its' potential benefits for the business community. Stimulating economic recovery in times of financial crisis, through the Commission's work on the European contract law, is one of the matters addressed in the Europe 2020 strategy (Note 1). Furthermore, in order to properly understand and function in highly competitive international environments, businesses need a code to follow, both internally and externally. It would also be reasonable from a good business 
practice point of view for the international parties to act according to a unified and transparent set of rules. Potentially, a harmonized approach to business conduct might also facilitate operational existence at an international level.

\section{Brief Historical Overview}

The first attempts at harmonization of Civil Law date back to the year 1989 when the European Parliament issued a Resolution with the aim of regulating action on the European Civil Code. Not much was done in this regard until 2001 when the European Commission published the Communication on European contract law to the European Parliament and Council. (Note 2)

The Communication presented four options to stimulate debate:

1. no action at all, in which case obstacles to cross-border trade would be resolved by interest groups or other parties;

2. harmonization of national laws via the promotion and development of common law principles;

3. the improvement of existing legislation by the review, modernization and simplification of existing directives;

4. the adoption of a new legislation at the EC level - either as an optional instrument to be chosen by the parties or as a mandatory code.

The Commission was confronted by responses from 180 stakeholders from academic, governmental, legal and business backgrounds, as well as from the EU institutions: the Parliament, Council, and Economic and Social Committee. The extent of feedback received was an undeniable indicator of interest in the concept of harmonization. (Note 3) The July 2001 Communication on European contract law opened the door for consultation and discussion about how to deal with the differences between national contract laws at the Member State level. In the spirit of the consultative process, two years later, the European Commission introduced the Action Plan. (Note 4) A mixture of non-regulatory and regulatory measures was recommended to solve the problems resulting from national divergences. At the heart of this initiative was the development of a Common Frame of Reference (CFR) to "ensure greater coherence of existing and future acquis in the area of contract, by establishing common principles and terminology and providing best solutions in terms of common terminology and rules i.e. the definition of fundamental concepts such as 'contract' or 'damage' and of the rules which apply, for example, in the case of non-performance of contracts" (Note 5), as well as to further examine whether problems in the European contract law area may require non-sector-specific solutions such as the introduction of an optional instrument (Note 6). In October 2004 the Commission published another Communication aimed at highlighting areas for improvement. Based on the feedback received from stakeholders from business and legal interest groups, a report entitled European contract law: the way forward was published in April 2005. (Note 7) Two Progress Reports on the Common Frame of Reference, (Note 8) as well as a Green Paper on the Review of the Consumer Acquis (Note 9), and a proposal for a Directive on consumer rights (Note 10) followed in 2007. As a result of the extensive consultations and combined efforts, in 2008 the Study Group on a European Civil Code and the Research Group on Existing EC Private Law presented the European Commission with a Draft Common Frame of Reference (DCFR), which was then published in February 2009.

\section{The Draft Common Frame of Reference}

The Draft Common Frame of Reference (DCFR) is first and foremost an academic text, separate from political dissertations or references to its' practical applicability. It contains a set of principles, definitions and model rules which the authors hope to be a "tool for better lawmaking." (Note 11) It is however cryptic what "better" means or which aspects of law it actually refers to. The question thus arises, in which regard would the DCFR be better than the existing national laws? The authors of the DCFR fail to present a comparison of this newly created tool with the existing system (which is implied to be 'worse') or with any other options for that matter. According to its' authors, the "toolbox" should enhance the understanding of the diverse legal systems within the EU as well as improve the overall quality of European legislation. (Note 12) The underlying principles governing the creation of the DCFR are freedom, security, justice and efficiency. The DCFR therefore fails to introduce any new solutions, but instead sheds doubt as to the quality of the existing legal system. It allows one to question what is wrong with the status quo. Otherwise, why would one attempt to fix something that is not faulty?

The overall purpose of the DCFR is to contribute to the promotion and facilitation of knowledge in the field of contract law in the EU by means of introducing a common European legislative system to render business transactions between EU countries easier and to fully optimize the single market. In this regard, the European Commission proposes the introduction of an optional instrument, translated into all EU official languages, which would embrace identical rules, common principles and joint terminology. By comparison to the UNIDROIT 
Principles, the PECL and the Guiding Principles of European Contract Law, the idea itself as well as its' objectives again lack originality. The only new element is the idea to translate this work into more EU languages in order to ensure that "Linguistic diversity will be respected (...)". (Note 13) This postulate is not free from flaws. Translation into "as many European languages as possible" (Note 14) will merely reflect Europe's linguistic diversity but not fully acknowledge it. Moreover, it is not clear exactly which languages will be given priority of translation. The quantitative measure of "as many as possible" is unclear and causes further doubt. How will the languages-to-be-translated group be designated - by status of official, procedural, minority or regional adherence? The only matter free from doubt is the dominance of one language. The DCFR was initially prepared and published in English. The working groups have commenced work on translations into other languages and promised to complete them "as quickly as possible" (Note 15). So far, since 2008, only the French and Czech versions have been made available. (Note 16)

Linguistic considerations aside, the DCFR and the subsequent Common Frame of Reference (CFR) must be clearly distinguished. The ultimate aim of the first instrument is to provide a model framework for the final end result of the harmonization process - the CFR. The harmonization project is not an attempt to create one single law for all the Member States. As underlined by the Study Group on a European Civil Code and the Research Group on EC Private Law (Acquis Group), “(...) the purpose of the CFR as a legislator's guide or toolbox is to enable the meaning of European legislation to be clear to people from diverse legal backgrounds. Moreover, existing cultural diversity was respected by the participation on an equal footing of lawyers from all European legal cultures in the preparation of the DCFR and by the serious attempt to reflect, as far as possible (italics added), all legal systems of the EU Member States in the Notes". (Note 17) The margin of safety introduced by the phrase 'as far as possible' allows one to question whether indeed all the legal systems within the EU have been covered by the DCFR and whether all these systems have been granted the same level of attention. Furthermore, the fact that the attempt of the authors was serious is mildly reassuring.

In the process of developing the CFR, the Commission takes into account the opinions gathered from consulting the stakeholders. The Commission confirms the above cited view by stating that "(...) it is neither the intention to propose a 'European civil code' which would harmonize contract laws of Member States, nor should the reflections be seen as in any way calling into question the current approaches to promoting free circulation on the basis of flexible and efficient solutions." (Note 18) In the Summary of the Report with Evidence it is reconfirmed that "The development of a harmonized code of European contract law (to which we remain opposed) appears to be off any foreseeable agenda." (Note 19) Contrarily to this statement, Professor Vogenauer points out that "The DCFR, as published in 2007, is much more than a 'toolbox' for a revision of the acquis, and it even goes beyond a potential European Contract Law Instrument. It is clearly meant to be a blueprint of a European Civil Code in the area of patrimonial law." (Note 20) The broad scope of the DCFR as well as its' form of a code seem to justify this opinion. The content of the DCFR contains all the information one would normally expect to find in a code. The only noticeable difference is its' structure. The whole text is compilation of ten Books. Instead of a division into articles, there are Chapters, Sections, Sub-sections, Articles and Comments followed by Notes containing information on legal systems of particular EU Member States. This is merely an optical change. Moreover, the authors of the Principles, Definitions and Model Rules of European Private Law explicitly designate themselves as "The Study Group on a European Civil Code" (italics added).

\section{Practical Aspects of Harmonization of European Contract Law}

Thus far, the proposal to harmonize European contract law seems to have raised more issues for discussion rather than it has offered practical solutions. One of the aspects which remain open is whether the harmonized system should apply to Business-to-Business (B2B) or Business-to-Consumer (B2C) transactions. For the sake of this article, let us assume that the scope of application will be limited to B2B operations. As companies grow and develop, they come to the point when they want to expand their scope of geographical market. Internationalization is the next logical step. For some businesses internationalization is an opportunity to prolong the life of their products or services once they have "outgrown" the domestic market. For others, internationalization becomes a necessity when the sector they operate is transformed into global. Exporting to other countries carries an opportunity to gain new experiences which may in turn increase competitiveness in the domestic arena. Although potentially advantageous, the process is not free from challenges and risks. Despite the various economic and social benefits related to the international expansion of companies such as, inter alia, increased productivity, enhanced competitiveness or growth in employment rate, there are several factors hindering the international exposure of businesses. One of the major drawbacks is the lack of confidence in success, which can partly be linked with insufficient public measures designed to strengthen the position of companies in the international arena. 
The most common barriers to internationalization are as follows:

$>$ Lack of adequate information;

$>$ Insufficient capital;

$>$ Lack of sufficient public support;

Costs or administrative complexity of transport;

$>$ Different laws and regulations in foreign countries;

$>$ Customs tariffs and other commercial barriers in foreign markets;

$>$ Customs tariffs and other commercial barriers in the domestic market;

$>$ Costs related to cultural diversity. (Note 21)

According to economists and specialists in internationalization, cultural and legal differences are smaller among the Member States than outside of the EU. According to the same authors, the EU strives to harmonize the procedures, a maneuver which should facilitate commercial transactions. The authors provide an example of intellectual law which, according to them, is more developed within Europe than outside of it. The same critics state that outside of the EU companies are confronted with different regulations and interpretations concerning matters related to patents, trademarks, licenses, patents, etc. (Note 22) I dare to disagree that only laws regarding intellectual property can influence international trade. Perhaps such a selective approach can explain the optimistic conclusions reached as far as the facilitation of trade is concerned. In my opinion the different laws and regulations related to economic cross border transactions, lack of uniform procedures related to customs tariffs, cultural diversity and different legal practice constitute equally serious barriers to international trade.

The degree of internationalization varies not only according to Member States, but also depending on the size of the company. As compared to large firms, especially SMEs are less skillful in dealing with external factors and imposed restrictions, such as limited access to financial instruments, know-how or legal assistance (Note 23). This dissonance between SMEs and large companies can best be illustrated on the example of Belgium. Belgium is one of the most international economies in the EU (Note 24). In 2008, the index of internationalization reached $85 \%$. Interestingly, this impressive figure can only partly be attributed to the activities of Belgium SMEs, which constitute only $26 \%$ of all international operations. If the gap between SMEs and large firms is so vast in one of Europe's most internationalized economies, by analogy, it only comes to show the extent of the phenomenon in other, less internationally developed and inclined Member States.

Provided that the introduction of an appropriate public measure could solve this discrepancy, there is fertile ground for the European Commission to investigate whether and how a harmonized system of European contract law could boost the international activities of European companies.

In a majority of cases, business practice supersedes lawmaking. The harmonized European contract law should therefore reflect modern business issues and be tailored to the current needs of an international mix of participants. In other words, the end result should be user focused in order to guarantee its' practical impact. In 2005 a survey of the attitudes of European businesses to the advantages and disadvantages of the harmonization process of European contract law was conducted by an independent company, Gracechurch Consulting, on request of the one of the world's biggest law firms, Clifford Chance. (Note 25) More importantly, it was the first questionnaire of this type to be conducted independently of the involvement of the European Commission. The results of the Clifford Chance survey were chosen to be presented and analyzed for the purposes of this paper due to their autonomous nature and objectivity. The survey covered four groups of questions related to the following aspects: the respondents' involvement in cross-border trade, national differences in contract law as an obstacle to cross-border transactions, the extent to which the new legislation has affected the status quo, and whether harmonization was indeed needed and if so, what form it should adopt. (Note 26) The survey comprised 175 companies from 8 Member States (France, Germany, Hungary, Spain, Italy, Poland, UK and the Netherlands) and 7 industries (consumer and retail, energy and resources, healthcare and life sciences, manufacturing and construction, professional and other services, technology, and transport). The main objective of the questionnaire was to gather views on the project of harmonization of European contract law, as well as investigate alternative options for the development of EU contract law. The results of the survey were meant to serve as an indicator for the European Commission on whether its' efforts towards harmonization are going in the right direction and whether the different national legal systems indeed constitute a trade barrier for the users of contract law.

The survey showed that $83 \%$ of all businesses and as much as $88 \%$ of the SMEs view the concept of harmonization favorably.

Despite the favorable approach to the idea of harmonization of a majority of respondents, only $54 \%$ thought that it is indeed achievable. This echoes the voices of criticism of those doubting that harmonization is a feasible 
undertaking. The reasons for the objections are multiple, the most important being the practical difficulties of developing a common European law, little likelihood of achieving mutual agreement among Member States due to legal, political and cultural differences, as well as particular difficulties involved with harmonizing common and civil law traditions. When it comes to the choice of governing law, $60 \%$ of the questioned population opted for the freedom of choice and responded that they would like a more comprehensive system, either substituting national laws or existing in addition to them, to be introduced. This reflects the Commission's proposal of the CFR as an optional instrument: “(...) the CFR could be a framework of EU law binding where parties chose to adopt it. Parties to a contract could decide to make such law the law applicable to their agreement, just as they are now able to agree that the law of a Member State or a third party could apply. Alternatively, there could be a presumption that the framework would be binding unless the parties agreed to exclude it. But the EU framework would not be mandatory". (Note 27) Quite logically, the practical use of this optional instrument would depend on its scope and quality. The factors making for a good contract law listed by the survey participants were as follows: ability to enable trade, fairness, predictability, briefness and conciseness, flexibility and prescriptive nature. Perhaps the most prominent conclusion derived from analysis of the Clifford Chance survey results was that, if given the choice, $83 \%$ of the respondents would take advantage of it and use the harmonized system.

\section{The Implications of Harmonization of European Contract Law on International Business Practice}

Although the above presented market research has confirmed that harmonization of European contract law would indeed be desirable, it did not bring up the fundamental question - what for? In other words, what are the underlying needs in international business practice which triggered $83 \%$ of favorable responses from the representatives of the business community? Undeniably, the already mentioned reduction of barriers to internationalization and stimulation of economic growth at the SME level can be regarded as possible benefits of the proposal to harmonize European contract law.

Question 3 of the above mentioned survey raised the issue of factors impacting the ability to conduct international business. The respondents were asked to rate on a scale of 1 to 10 the following: language, variations between legal systems, cultural differences, differences in implementation of EU directives, bureaucracy/corruption, cost of obtaining foreign legal advice and tax. The latter was seen as having the highest impact. As suggested by some authors, "(...) legal professionals may seek - and should be able - to render the law more formalistic, more complex and more technical than is economically optimal, because this enhances the demand for their services." (Note 28) The introduction of a harmonized instrument could potentially reduce costs of legal advice, minimize the need for outsourcing of legal expertise and simplify the process of adapting contracts to different national laws in the course of international business activities. Consequently, unification of both internal and external procedures could lead to substantial savings in time, effort and energy. Undoubtedly, it is much easier to conduct business according to a standard set of principles rather than to follow a confetti of business practices which vary according to company culture, location and branch. Enhanced understanding resulting from the introduction of a harmonized system might in turn have an immediate reflection in the reduction of transaction and operational costs. These are not arguments that companies can light-heartedly reject in harsh economic market conditions. Among the practical difficulties of developing and introducing a common European contract law perhaps the most critical is little likelihood of achieving mutual agreement among Member States of the EU due to legal, socio-political and cultural differences, as well as particular obstacles involved with harmonizing common and civil law traditions. The thread bringing this patchwork of legal, political, economic and cultural barriers together is undoubtedly communication and more specifically - language. In case of miscommunication the linking thread may easily transform into a fuse. May the harmonization of European contract law thus facilitate the resolution of conflicts which might occur in the course of the international business activities? The use of the notion "facilitate" was a deliberate choice on my part. The common belief is that conflict is natural, inevitable and lies within human nature. The Wheel of Conflict, a concept introduced by B. Mayer, best represents the forces which cause and drive conflict. (Note 29) It comprises the following elements: communication, emotions, history, structure, values and needs which function interactively and continuously affect each other. International economic transactions involve a majority, if not all, of these conflict components.

Many conflicts arise because one party assumes it has expressed itself in accurate terms when in fact it has not. When the other party then acts in accordance with different (misunderstood) information and assumptions, it is perceived as acting in bad faith. Language and cultural differences greatly add to the miscommunication effect. Business transactions are not free from emotions. When stakes are high, it is sometimes difficult to rationalize and control behavior, especially if values and beliefs are added to the mix. Individual and cultural characteristics, components of the organizational culture, sometimes make it difficult to properly "read" other parties. What may be important to the representatives of one nationality may not be seen as such by another. From here, there is only 
a small step towards the outbreak of conflict. Emotions and values are driven by the fundamental element - needs. Human need is the driver of all actions, including involvement in business activity. Structure is also identified as one of the key components of the Wheel of Conflict. As B. Mayer points out "An example is the litigation process, one structure for decision making when people are in conflict. Litigation is well designed for achieving a decisive outcome when other less adversarial procedures have not worked. However, it is also a structure that exacerbates conflict, makes compromise difficult, and casts issues as win-lose struggles". (Note 30) History, understood as different traditions, approaches to conducting business and legal cultures, may also have a bearing on conflict in the sense that established business practice and organizational culture may determine future actions and either prevent or cause conflict.

The conclusion derived from the above brief analysis of the structural elements of conflict is that international business transactions carry a heavy potential for conflict. Without adequate means the field of international contract law can easily turn into a battle field. The EU contract law harmonization proposal may facilitate the resolution of this dilemma.

\section{Conclusions}

This brief analysis has shown that the concept of harmonization of European contract law is a complex and controversial topic which has already given rise to fervent discussions (Note 31) and attracted criticism from both academics, practitioners and representatives of the legal and business community. Voices of critique are numerous; however most seem to follow a similar pattern. Literature on the subject inevitably refers to the same source documents and raises analogous issues but from a different angle. Entangled in the web of discussion on the drawbacks, general aspects, overall feasibility, possibilities and difficulties of harmonization, few have the courage to derail the established train of thought and ask the fundamental if not somewhat unsettling question: What could be the practical benefits of introducing a harmonized system of European contract law for international business? Posing this question at such an advanced stage of developments in the harmonization process is somewhat like shutting the stable door after the horse has bolted. Nevertheless, it is critical in order to draw attention to such potential benefits as: reduction of barriers to internationalization and stimulation of economic growth at the SME level, enhanced understanding of standards and procedures of business conduct, reinforced communication between international parties, lower transaction and operational costs, less need for external expertise and legal advice, and prevention of potential conflicts. In conclusion, a results-driven, clear focus on the practical advantages of the harmonization of European contract law can ultimately transform what is now merely an academic exercise into a practical business tool. At the end of the day, the expected benefits will be the primordial factor affecting international companies' rejection or acceptance of the harmonization proposal.

\section{References}

Doris, M. J. (2008). Dispute Avoidance and European Contract Law: Dealing with Divergence. Europa Law Publishing.

Drobnig, U. (1996). Private Law in the European Union. Kluwer Law International.

Grundmann, S. (2002). An Academic Green Paper on European Contract Law. Kluwer Law International.

Hesselink, M. W. (2002). The New European Private Law: Essays on the Future of Private Law in Europe. Kluwer Law International.

Hondius, E. H. (2004). Towards a European Civil Code. Kluwer Law International.

Lernoux, F., Boschmans, K., Bouyon, S., Martin, I., \& Van Caillie, D. (2013). Internationalisation des PME. Comment réussir à l'étranger. De Boeck \& Larcier.

Mattei, U., \& Cafaggi, F. (1998). Comparative Law and Economics. In New Palgrave Dictionary of Economics and the Law (Vol. I). Macmillan, London.

Mayer, B. (2000). The Dynamics of Conflict Resolution, A Practitioner's Guide. Jossey-Bass, San Francisco, CA.

McKendrick, E. (2006). The State We Are In. In The Harmonization of European Contract Law, Harmonization of European Contract law. Hart Publishing.

Smits, J. (2005). The Need for a European Contract Law: Empirical and Legal Perspectives. Europa Law Publishing.

Vogenauer, S., \& Weatherhill, S. (2006a). The Harmonisation of European Contract Law: Implications for European Private Laws, Business and Legal Practice. Hart Publishing, Oxford and Portland, Oregon.

Vogenauer, S., \& Weatherill, S. (2006b). The Harmonization of European Contract law, The EC's Competence to 
Pursue the Harmonization of Contract law - an Empirical Contribution to the Debate. Hart Publishing, Oxford and Portland, Oregon.

Werro, F. (2004). Le droit privé suisse face au droit communautaire européen : Questions actuelles en droit de la responsabilité civile et en droit des contrats. Berne.

\section{EU Legislation}

Communication from the Commission to the European Parliament and the Council. A More Coherent European Contract Law. An Action Plan, COM (2003) 68 final.

Communication on EU Contract Law, COM (2001) 398; A More Coherent European Contract Law, COM (2003) 68, European Contract Law and Revision of the Acquis: The Way Forward, COM (2004) 651.

Doc 10996/01; COM (2001) 398.

Doc 14183/08; COM (2008) 614.

Doc 6307/07; COM (2006) 744.

Docs 13065/05 and 12269/07.

European Commission, Communication to the Council and the European Parliament on European Contract Law, COM (2001) 398, OJ 2001 C 255/1.

House of Lords, European Union Committee, 12th Report of Session 2008-09, European Contract Law: the Draft Common Frame of Reference, Report with Evidence, published by the Authority of the House of Lords, London: the Stationery Office Limited, Chapter 2: History of the Common Frame of Reference.

COM (2003) final OJ C 63/1.

COM (2010) 2020 final. P. 21, 3.3.2010. The Single Market Act (COM(2011) 206 final, 13.4.2011), the Annual Growth Survey, Annex 1, progress report on Europe 2020 (COM(2011) 11-A1/2), the Digital Agenda for Europe (COM(2010) 245 final, 26.8.2010) and the Action Plan Implementing the Stockholm Programme (COM2010) 171 final, 20.4.2010).

\section{Notes}

Note 1. COM(2010) 2020 final. p. 21, 3.3.2010. The Single Market Act (COM(2011) 206 final, p. 19, 13.4.2011), the Annual Growth Survey, Annex 1, progress report on Europe 2020 (COM(2011) 11-A1/2, p. 5), the Digital Agenda for Europe (COM(2010) 245 final 12, p. 13 and 37, 26.8.2010) and the Action Plan Implementing the Stockholm Programme (COM2010) 171 final, p. 5 and 24, 20.4.2010).

Note 2. Doc 10996/01; COM (2001) 398.

Note 3. E. McKendrick In: The Harmonization of European Contract Law, Harmonization of European Contract Law: The State We Are In, Hart Publishing, 2006, p. 10-11.

Note 4. COM (2003) final OJ C 63/1.

Note 5. House of Lords, European Union Committee, 12th Report of Session 2008-09, European Contract Law: the Draft Common Frame of Reference, Report with Evidence, published by the Authority of the House of Lords, London: the Stationery Office Limited, Chapter 2: History of the Common Frame of Reference, p. 9.

Note 6. Communication from the Commission to the European Parliament and the Council. A More Coherent European Contract Law. An Action Plan, COM(2003) 68 final, p. 2.

Note 7. European Union Committee, 12th Report (2004-05): European contract law: the way forward (HL 95).

Note 8. Docs 13065/05 and 12269/07.

Note 9. Doc 6307/07; COM(2006) 744.

Note 10. Doc 14183/08; $\operatorname{COM}(20080614$.

Note 11. Principles, Definitions and Model Rules of European Private Law Draft Common Frame of Reference (DCFR), Outline Edition. Prepared by the Study Group on a European Civil Code and the Research Group on EC Private Law (Acquis Group).Based in part on a revised version of the Principles of European Contract law. Edited by Christian von Bar, Eric Clive and Hans Schulte-Nölke, Hugh Beale, Johnny Herre, Jérôme Huet, Matthias Storme, Stephen Swann, Paul Varul, Anna Veneziano and Fryderyk Zoll.Sellier, European Law Publishers, (Munich 2009), p. 29. 
Note 12. House of Lords, European Union Committee, 12th Report of Session 2008-09, European Contract Law: the Draft Common Frame of Reference, Report with Evidence, published by the Authority of the House of Lords, London: the Stationery Office Limited, Summary.

Note 13. Principles, Definitions and Model Rules of European Private Law Draft Common Frame of Reference (DCFR), Full Edition, p. 9.

Note 14. Idem.

Note 15. Principles, Definitions and Model Rules of European Private Law Draft Common Frame of Reference (DCFR), Full Edition. Prepared by the Study Group on a European Civil Code and the Research Group on EC Private Law (Acquis Group). Based in part on a revised version of the Principles of European Contract law. Edited by Christian von Bar and Eric Clive, European Law Publishers, (Munich 2009), p. 15.

Note 16. French: by Professor Jacques Ghestin (Paris) and Czech: by Professor Premysl Raban.

Note 17. Idem, p. 9.

Note 18. European Contract Law and Revision of the Acquis: The Way Forward, COM (2004) 651, p. 8.

Note 19. House of Lords, European Union Committee, 12th Report of Session 2008-09, European Contract Law: the Draft Common Frame of Reference, Report with Evidence, published by the Authority of the House of Lords, London: the Stationery Office Limited, Summary.

Note 20. Professor Vogenauer made this remark when he supplied the Committee with a copy a newspaper article in which Professor Gerhard Wagner of Bonn University refers to the DCFR as an "ugly phrase" which covers the fact that it is nothing less than a draft of a European Code of Civil Law, (ZEuP, 4/2008).

Note 21. F. Lernoux, K. Boschmans, S. Bouyon, I. Martin, D. Van Caillie, Internationalisation des PME. Comment réussir à l'étranger, De Boeck \& Larcier, 2013, p. 38.

Note 22. Idem, p. 37.

Note 23. For more information on access to finance for SMEs in the euro area, consult: http://ec.europ a.eu/enterprise/policies/finance/data/enterprise-finance-index/european-surveys/ecb-surveys/index_en.htm.

Note 24. According to the annual internationalization index established by Ernst\&Young.

Note 25. For more details see: S. Vogenauer, S. Weatherill (Eds.), The Harmonization of European Contract law, The EC's Competence to Pursue the Harmonization of Contract law - an Empirical Contribution to the Debate, Hart Publishing, Oxford and Portland, Oregon, 2006, pp. 105-148.

Note 26. Idem, p. 119.

Note 27. House of Lords, European Union Committee, 12th Report of Session 2008-09, European Contract Law: the Draft Common Frame of Reference, Report with Evidence, published by the Authority of the House of Lords, London: the Stationery Office Limited, p. 20.

Note 28. U. Mattei, F. Cafaggi (1998), 'Comparative Law and Economics' in New Palgrave Dictionary of Economics and the Law, vol. I, Macmillan, London, p. 346-52.

Note 29. B. Mayer, The Dynamics of Conflict Resolution, A Practitioner's Guide, Jossey-Bass, San Francisco, CA, 2000.

Note 30. Idem, p. 12-13.

Note 31. See various EU Consultations, Communication on EU Contract Law, COM (2001) 398; A More Coherent European Contract Law, COM (2003) 68, European Contract Law and Revision of the Acquis: The Way Forward, COM (2004) 651.

\section{Copyrights}

Copyright for this article is retained by the author(s), with first publication rights granted to the journal.

This is an open-access article distributed under the terms and conditions of the Creative Commons Attribution license (http://creativecommons.org/licenses/by/3.0/). 